\title{
PRASYARAT KOMPETENSI LINTAS BUDAYA DAN KETAHANAN BAGI PASUKAN PENJAGA PERDAMAIAN PBB: SEBUAH USULAN PELATIHAN
}

\author{
Raden Mas Jerry Indrawan \\ Universitas Pembangunan Nasional "Veteran" Jakarta \\ jerry_indrawan18@yahoo.co.id
}

\begin{abstract}
Does culture pose significant threat to UN Peacekeeping Forces in their line of duty in conflict areas? Does it affect their role as peacekeepers in the midst of conflicts? Peacekeeping is not an ordinary military assignment, like in war. Peacekeeping Operation requires certain skills, such as cross-cultural competence and high cultural resilience. Hence, peacekeeping work must be understood as an activity that rely more on cooperation, integration from all related stakeholders, and coordination between the UN Peacekeeping Mission with other parties, like civilians, government, police, humanitarian workers, mass media, etc. Today, the complexity of UN missions requires variation in their training methods. This paper will discuss several of training programs involving the entire component of peacekeeping forces, including their family, regarding to cross-cultural competence and cultural resilience.
\end{abstract}

Keywords: Cross-Cultural Competence Training, Resiliency, Peacekeeping Forces, Multi-cultural, and Prejudice.

\begin{abstract}
Abstrak
Apakah budaya menimbulkan ancaman yang signifikan untuk Angkatan Penjaga Perdamaian PBB di garis mereka bertugas di daerah konflik? Apakah itu mempengaruhi peran mereka sebagai pasukan penjaga perdamaian di tengah-tengah konflik? Penjaga perdamaian bukan tugas militer biasa, seperti dalam perang. Operasi Penjaga Perdamaian membutuhkan keterampilan tertentu, seperti kompetensi lintas budaya dan ketahanan budaya yang tinggi. Oleh karena itu, pekerjaan penjaga perdamaian harus memahami sebagai aktivitas yang lebih mengandalkan kerjasama, integrasi dari semua pemangku kepentingan terkait, dan koordinasi antara Misi Perdamaian PBB dengan pihak lain, seperti warga sipil, pemerintah, polisi, pekerja kemanusiaan, media massa, dll saat ini, kompleksitas misi PBB membutuhkan variasi dalam metode pelatihan mereka. Tulisan ini akan membahas beberapa program pelatihan yang melibatkan seluruh komponen pasukan perdamaian, termasuk keluarga mereka, sehubungan dengan kompetensi lintas budaya dan ketahanan budaya
\end{abstract}

Kata Kunci: Pelatihan Kompetensi Lintas Budaya, Ketahanan, Pasukan Penjaga Perdamaian, Multi-Kultural, dan Prasangka.

\section{Pendahuluan}

Dalam konteks hubungan internasional, proses perdamaian tidak dapat begitu saja terjadi, apalagi mengharapkannya terjadi dari sebuah situasi yang awalnya vakum (idle). Proses perdamaian membutuhkan proses pengambilan keputusan yang profesional, analisa 
permasalahan yang komprehensif dan solutif, serta berani mengambil resiko untuk kepentingan bersama. Terkadang, dalam upaya-upaya perdamaian yang terjadi malah meningkatnya kekerasan dan instabilitas, parahnya lagi hal ini terjadi kurang cakapnya pihak-pihak yang berupaya mengatasi konflik tersebut untuk membaca situasi dan berhadapan dengan keadaan yang sama sekali berbeda dengan keadaan biasanya.

Kecenderungan sebuah konflik, apalagi konflik etnis, untuk berubah menjadi aneh atau khas bisa dibilang, membutuhkan penyesuaian dari pihakpihak yang menjadi resolutornya. Konflik etnis pastinya terkait budaya lokal, tapi ia tidak digerakkan oleh halhal, seperti tradisi, kesukuan, adat, atau karena masalah-masalah biologis. Konflik etnis sekarang umumnya terjadi karena modernitas, alasan-alasan yang logis, sumber daya, dll (Darby dan Mac Ginty 2003: 7). Karena itu, untuk menyelesaikannya diperlukan pendekatan-pendekatan modern, rasional, tetapi tetap tidak menghilangkan nuansa kultural etnisitasnya.

Dewasa ini, pelatihan bagi personel militer, polisi, dan orang sipil untuk pasukan penjaga perdamaian PBB sudah dianggap sebagai faktor yang sangat penting untuk efektivitas misimisi perdamaian di lapangan. Akan tetapi, hal ini tidaklah selalu menjadi faktor utamanya. Pelatihan yang diberikan bagi personel-personel untuk misi-misi perdamaian sangat berbeda pada waktu sebelum dan sesudah Perang Dingin. Baru pada awal tahun 1990-an keperluan untuk penyesuaian pelatihan tambahan yang spesifik untuk misi-misi perdamaian dikenal.
Kebutuhan akan pelatihan tambahan ini diperlukan karena di lapangan ditemukan cukup banyak muncul masalah terkait budaya lokal daerah yang bersangkutan. Masalah cultural gap ini sebenarnya cukup kompleks untuk diselesaikan, dan terkadang memiliki tingkat signifikansi yang tinggi dalam upaya-upaya penyelesaian konflik. Karena itu, sebaiknya setiap pasukan penjaga perdamaian yang akan diterjunkan dapat memiliki keahlian dalam hal pemahaman lintas budaya.

Secara khusus, berevolusinya kompleksitas dan multi-dimensinya misi-misi perdamaian, dalam hubungannya dengan tantangantantangan baru yang diberikan oleh kondisi-kondisi pasca-konflik kontemporer dewasa ini, mendorong pentingnya perubahan bagi pelatihanpelatihan yang selama ini diberikan. PBB dengan segera menyadari bahwa pasukan penjaga perdamaian yang ideal, terpisah dari latihan-latihan mereka sebagai seorang tentara, memerlukan latihan tambahan yang akan disesuaikan dengan hal-hal baru yang dihadapi para pasukan perdamaian dewasa ini. Tentunya tidak hanya personel militer, pelatihan tambahan ini diperlukan bagi personel sipil di dalamnya, ditambah akan dibahas pula tentang keluarga para pasukan perdamaian agar mereka juga memiliki ketahanan budaya.

Salah satu contoh menarik adalah apa yang diterapkan pasukan Kanada dalam mengembangkan pendekatan sistematis untuk pelatihan-pelatihan pasukan perdamaian PBB. Pasukan Kanada adalah pasukan yang dilatih untuk menghadapi perang dingin di era tahun 60-an sampai 90-an, tetapi mereka pun dilengkapi dengan kemampuan beroperasi dalam kegiatan- 
kegiatan perdamaian. Mereka juga dilatih untuk siap ditempatkan pada daerah-daerah konflik sebagai pasukan penjaga perdamaian (peacekeepers). Walaupun, pelatihan-pelatihan seperti ini dirasa cukup, tetapi pelatihan ini pun masih dirasa kurang dalam hal penekanan pada doktrin, standar, dan metode evaluasi terkait operasi-operasi penjaga perdamaian. Para pasukan Kanada yang bertugas sebagai pasukan penjaga perdamaian ini juga pada dasarnya mengalami kesulitan dalam berinteraksi dengan warga lokal (Peace Operation Training Institute, 2007).

Tahun 1964, SOP (Standard Operating Procedures) baru diterapkan untuk para pasukan yang terlibat dalam misi-misi perdamaian. Salah satu SOPnya adalah disediakannya tambahan pelatihan, seperti taklimat (briefing) terhadap isu-isu khusus dalam sebuah misi perdamaian. Akan tetapi, penambahan pelatihan-pelatihan prapemberangkatan ini terganjal masalah terbatasnya latar belakang informasi yang didapatkan mengenai negara yang akan menjadi tujuan keberangkatan, seperti keadaan geografis dan populasi penduduknya.

Banyak pelatihan-pelatihan khusus seperti ini hanya dilakukan atas pertimbangan penting atau tidaknya pelatihan tersebut menurut perwira tinggi mereka. Jadi, jika para perwira tinggi merasa bahwa pelatihan khusus diperlukan untuk misi tertentu, maka barulah pelatihan-pelatihan tersebut dilakukan. Dan saat dilakukan pun, umumnya pelatihannya bersifat sporadis dan fokusnya hanya pada tugas-tugas seperti yang dilakukan aparat kepolisian. Ini pun ternyata tidak diterapkan kepada seluruh pasukan penjaga perdamaian, hanya beberapa yang menerima pelatihan khusus untuk peacekeepers ini. Inisiatif pasukan Kanada pada masa itu sudah sangat baik untuk memasukkan juga materi-materi pelatihan khusus untuk pasukan penjaga perdamaian (Peace Operation Training Institute, 2007). Walaupun masih banyak hambatan yang muncul, serta program-program pelatihan yang perlu dibenahi dan ditambah, pencapaian yang dilakukan pasukan Kanada ini perlu diapresiasi.

Pelatihan-pelatihan khusus yang terkait kompetensi lintas budaya dan ketahanan para peacekeepers, serta keluarganya menjadi sulit apabila hanya dilakukan secara ad hoc saja. Perlu dibuat sebuah program pelatihan jangka panjang yang simultan dan holistis terhadap semua misi-misi perdamaian di bawah PBB. Memang, kesulitan utamanya adalah menyesuaikan pelatihan model apakah yang cocok dengan para peacekeepers (baik militer maupun sipil) dan keluarganya, serta lingkungan baru di mana mereka akan ditempatkan nantinya, mengingat konflik-konflik yang terjadi dewasa ini yang sangat sulit diprediksi. Untuk itu, sangat penting bagi kita untuk memastikan bahwa tingkat disiplin dan pelatihan yang diberikan bagi semua pasukan perdamaian berjalan dengan baik dan optimal, serta memastikan juga bahwa mereka memiliki peralatan dan semua sumber daya yang dibutuhkan untuk menjalankan tugas yang ke depan akan semakin kompleks dan berbahaya (Eade, 2007: 65).

Pada sekitar tahun 1990-an, masyarakat internasional secara perlahan mulai menyadari bahwa perlunya dibuat sebuah pelatihan dalam hal kompetensi lintas budaya dan ketahanan bagi penjaga perdamaian ketika berada dalam situasi misi-misi perdamaian. Hal ini akan membuat para 
peacekeepers meresponi dengan optimal situasi-situasi yang membutuhkan pendekatan yang bersifat tradisonal dan tipe-tipe operasi perdamaian yang membutuhkan ketahanan tinggi (Cacioppo et al, 2001: 45).

Karena itu, penjaga perdamaian yang ideal tidak hanya pasukan yang mampu bertempur dan melakukan beberapa pekerjaan sekaligus (multipurpose), tetapi juga harus memiliki kemampuan tambahan, seperti kemampuan negosiasi dan mediasi dalam situasi konflik. Selain itu, penjaga perdamaian yang handal juga harus memiliki pengetahuan umum tentang sistem dan mandat PBB, pengetahuan yang mendasar dan luas tentang aturan keterlibatan dalam kondisi baku tembak (rules of engagement), mengerti tentang kerjasama sipil-militer dan bantuan kemanusiaan (mengingat dalam misimisi perdamaian sekarang ini keterlibatan sipil sudah semakin signifikan), maupun juga pengetahuan yang sifatnya khusus, seperti paham adat-istiadat lokal, budaya, dan juga bahasa. Kemampuan seperti ini yang disebut dengan kompetensi lintas budaya yang wajib diajarkan dalam program-program latihan khusus peacekeepers (Cacioppo et al, 2001: 46).

Jadi, sejak intensitas pasukan penjaga perdamaian yang dikirim ke dalam situasi berbahaya semakin meningkat, tanggung jawab mereka tidak hanya meningkat pula, tetapi juga semakin berbahaya pastinya. Perubahan lingkungan dalam misi-misi perdamaian seperti ini membuat kita harus lebih memfokuskan diri pada pelatihanpelatihan khusus bagi para personel penjaga perdamaian karena pasca komunis jatuh di tahun 1990-an, semakin banyak konflik-konflik internal dalam sebuah negara yang bermunculan, sehingga selain seorang tentara harus memiliki kemampuan bertarung, kompetensi lintas kultural dan ketahanan harus juga mereka miliki, dan diajarkan dalam sebuah program pelatihan yang permanen (institutionalize) (Cacioppo et al, 2001: $50)$.

Program pelatihan yang terkait ketahanan bagi keluarga peacekeepers juga harus diadakan mengingat intensifnya misi-misi perdamaian yang dilakukan $\mathrm{PBB}$, sehingga para peacekeepers semakin sering meninggalkan keluarga di rumah. Kondisi stres, khawatir, dll muncul dalam diri keluarga para keluarga peacekeepers sehingga diperlukan metode pelatihan yang tepat untuk bagaimana meningkatkan ketahanan mereka menghadapi masalah ini (Saltzman et al, 2011: 215). Untuk program ketahanan para keluarga peacekeepers akan dijelaskan pada bagian program ketahanan keluarga.

Berikut ini akan dibahas beberapa pola-pola program pelatihan yang akan melibatkan seluruh komponen pasukan perdamaian, dengan melibatkan keluarga mereka, terkait kompetensi lintas budaya dan ketahanan mereka dalam penugasannya di daerah misi. Mulai dari pelatihan lintas budaya dan peningkatan ketahanan sosial bagi pasukan penjaga perdamaian, serta bagaimana meningkatkan ketahanan bagi keluarga mereka ketika ditinggal pergi untuk bertugas. 


\section{Hal-hal yang Diperlukan untuk Melatih Pasukan Penjaga Perdamaian}

Kegiatan penjaga perdamaian (peacekeeping) harus dimaknai sebagai sebuah kegiatan yang mengandalkan kerjasama, membutuhkan integrasi dari semua elemen-elemen yang terlibat di dalamnya, serta koordinasi antara misi perdamaian PBB dan pihak-pihak lain yang tidak berhubungan langsung dengan misi, seperti orang-orang sipil, pemerintah, kepolisian, pekerja kemanusiaan, media massa, dll.

$$
\text { Kompleksnya }
$$

misi-misi

perdamaian PBB dewasa ini membuat program-program latihannya pun harus variatif dan komprehensif, dengan memperhatikan pada tiny details yang terkadang suka dilupakan. Beberapa materi-materi pelatihan yang bisa diberikan terkait kompetensi lintas budaya adalah soal sensitivitas gender, hak-hak dan perlindungan anak, serta eksploitasi dan penyiksaan seksual. Isuisu ini penting karena norma-norma yang ada dalam setiap negara terkait isu-isu ini tidaklah sama. Beberapa negara memiliki budaya yang limited pada perempuan dan anak-anak. Di negara-negara Arab dan Asia contohnya, perempuan tidak memiliki hak-hak yang sama dengan laki-laki. Hal ini membuat perlakuan terhadap mereka harus dibedakan. Para personel penjaga perdamaian harus mengerti ini karena salah perlakuan terhadap mereka dapat menimbulkan konflik di masyarakat lokal, apalagi jika sampai ada kasus sexual harassment. Pelatihan yang terkait dengan gender dijadikan sebagai prioritas oleh PBB untuk memastikan bahwa semua penjaga perdamaian belajar tentang isu-isu gender seperti yang tertuang dalam Security Council Resolution 1325 on
Women, Peace and Security (Office of the Special Adviser on Gender Issues and Advancement of Women, 2000).

Begitu pula dengan anak-anak. Di beberapa negara Afrika, kita mengenal tentara anak, di mana anak-anak di bawah umur direkrut untuk menjadi tentara dengan upah yang sangat kecil. Bahkan, beberapa dari mereka diculik dari kamp-kamp pengungsi untuk kemudian dieksploitasi oleh tentara pemberontak atau bahkan tentara pemerintah sendiri di sana (BBC Indonesia, 2011).

Begitu pula dengan kasus-kasus seksual yang banyak menimpa masyarakat lokal apabila ada tentara asing di daerah mereka. Bukan rahasia umum lagi kalau banyak tempat-tempat prostitusi yang bermunculan jika di daerah tersebut ada kamp atau pangkalan militer, termasuk juga yang dilakukan militer Amerika Serikat (Analisa Daily, 2012).

Untuk itu, para peacekeepers harus mengerti perbedaan kombatan dan bukan kombatan. Karenanya, diperlukan sensitivitas yang tinggi untuk dapat bertindak sebagai seorang penjaga perdamaian yang profesional, karena kita tidak bisa sekedar melihat dengan kacamata hitam putih belaka. Pengetahuan yang dalam tentang budaya begitu penting dalam misi-misi perdamaian, antara lain karena hal-hal demikian. Peacekeepers bukanlah ordinary soldiers, mereka punya tanggung jawab yang lebih besar daripada sekedar menjalankan tugastugas kemiliteran. Apalagi sekarang keterlibatan sipil di misi-misi perdamaian tersebut semakin memegang peranan penting.

Selain tiga hal di atas, personel penjaga perdamaian juga sebaiknya memiliki kemampuan menganalisa 
kasus-kasus yang terkait perdagangan manusia. Hal ini karena dalam setiap konflik yang timbul, yang dirugikan selalu adalah masyarakat. Di tengahtengah kondisi demikian, akses terhadap sumber daya pastinya terbatas. Karena itu, tidak heran jika sering terjadi praktek perdagangan yang melibatkan para pengungsi atau orang-orang yang daerahnya terkena dampak konflik. Mereka terkadang rela menjual dirinya sendiri kepada para penyelundup dengan alasan ekonomi dan menghindari konflik (Catholic Relief Service, tanpa tanggal).

Kerjasama sipil-militer juga diperlukan dalam misi-misi perdamaian, apalagi seperti yang sudah disebutkan di atas, peran pihak sipil dalam misi perdamaian PBB sudah semakin signifikan. Hubungan sipil-militer diperlukan untuk meningkatkan kemampuan personel militer dalam hak berkomunikasi dan berkoordinasi tentang langkah-langkah penyelesaian konflik dengan kelompok-kelompok sipil lokal. Jadi, tidak hanya bergantung pada personel sipilnya saja, personel militer pun harus memiliki kemampuan berkomunikasi dengan pihak-pihak sipil lokal. Pelatihan akan kesadaran terhadap pentingnya kompetensi lintas budaya berkontribusi sangat signifikan kepada ketahanan para penjaga perdamaian (baik personel sipil maupun militer) untuk beradaptasi di lingkungan lokal.

Diantara para personel penjaga perdamaian sendiri diperlukan pemahaman yang lebih luas tentang apa arti peacekeeping sendiri. Dewasa ini makna peacekeeping memang harus mengalami perluasan makna sehingga unsur-unsur yang tadinya tidak diperhatikan, seperti budaya, sekarang menjadi elemen utama dalam setiap pelatihan-pelatihan yang diajarkan sebelum memulai tugas. Batasanbatasan bahasa, kebiasaan-kebiasaan militer (military costumary), latar belakang pendidikan atau pelatihan dari para personel pengaja perdamaian yang berbeda-beda, semakin menegaskan perlunya keseragaman pelatihan kepada setiap kontingen penjaga perdamaian.

\section{Pelatihan Kompetensi Budaya}

Sebenarnya yang dimaksud pelatihan kompetensi budaya bisa kita artikan secara umum sebagai pelatihanpelatihan dan kurikulum yang bertujuan untuk meningkatkan kapabilitas dan efisiensi seorang individu untuk bekerja dalam lingkungan yang multi-kultural, baik dalam sebuah negara (seperti, pelatihan multi-kultural untuk konselor yang bekerja dengan etnik-etnik minoritas di dalam sebuah masyarakat) dan juga lintas batas negara (seperti, pelatihan multi-kultural prapemberangkatan untuk ekspatriat yang akan melakukan tugas-tugas di luar negeri (Rasilius, 2001).

Dalam dunia konseling, kurikulum untuk mempromosikan kompetensi budaya termasuk mengikuti kursus, berpartisipasi dalam lokakaryalokakarya, bacaan mandiri, instropeksi, dan beberapa bentuk-bentuk aktivitas pendalaman budaya lainnya, menyangkut kontak lintas budaya. Elemen-elemen pelatihan ini telah diadopsi secara luas untuk meningkatkan kompetensi budaya seseorang (Rasilius 2001).

Purwarupa dari kursus-kursus tentang multi-kultural yang difokuskan untuk pendekatan terhadap populasi khusus (contohnya mempelajari sejarahnya, budayanya, dan nilai-nilai dari kelompok-kelompok ras minoritas), meningkatkan jumlah bahan-bahan dan 
kursus-kursus tentang identitas sosial, seperti contohnya usia dan generasi kelompok, gender, orientasi seksual, status disabilitas, kelas ekonomi, dan sebagai tambahan, juga termasuk ras dan etnisitas (Rasilius 2001).

Secara organisasional, pelatihan kompetensi budaya bisa dibedakan bersama dua dimensi berikut: isi dan metode. Dimensi isi berkisar dari menyediakan peserta pelatihan dengan informasi yang spesifik tentang budaya, yang akan melengkapi mereka dengan pengetahuan budaya daerah tertentu, sampai informasi budaya secara umum, dengan tujuan untuk membuat mereka sadar akan yang namanya perbedaanperbedaan budaya. Dimensi metode cukup variatif, mulai dari pembelajaran intelektual sampai pembelajaran eksperimental. Adapun metode-metode yang lama mengajarkan pengetahuan melalui metode penyampaian tradisional (melalui pengajaran di kelas atau buku-buku contohnya), dimensi metode ini tidak lagi menggunakan metode lama, akan tetapi metode baru di mana pengetahuan diajarkan melalui latihan-latihan dan praktek-praktek (Chao, et al, 2001: 263)

Diantara bervariasinya tipe-tipe pelatihan, teknik asimilator budaya telah mendorong banyaknya ketertarikan untuk melakukan riset. Teknik ini bisa disesuaikan ke dalam pelatihan budaya-umum atau budayaspesifik. Secara umum, peserta pelatihan akan diberikan sebuah kisah tentang interaksi lintas budaya dan ditawarkan empat sampai lima alternatif putusan. Tanggapan akan diberikan kepada peserta pelatihan untuk menjelaskan apakah pilihan mereka sesuai atau tidak dengan konteks budaya yang diberikan tadi (Chao et al, 2001: 264).
Tinjauan terhadap kursus-kursus multi-kultural ini dalam program konseling psikologi dan programprogram pelatihan lintas budaya untuk ekspatriat menemukan bahwa umumnya kurikulum yang diberikan bertujuan untuk menyatukan beberapa aspek model tripartit dari kompetensi budaya untuk meningkatkan kesadaran, pengetahuan, dan skill para peserta pelatihan dalam menangani situasi multi-kultural (Chao et al, 2001: 264). Walaupun, pelatihan dan kurikulum ini ditujukan untuk meningkatkan kompetensi budaya, kritik terhadap mereka juga berdatangan. Bagian berikut akan membahas tantangantantangan yang dihadapi oleh pelatihanpelatihan budaya.

\section{Tantangan-Tantangan terhadap Kompetensi Budaya}

Walaupun, pelatihan kompetensi kultural mencoba untuk menyatukan beberapa aspek dari komponenkomponen seperti kesadaran, pengetahuan, dan skill, penekanan yang lebih berat ditekankan pada aspek pengetahuan untuk betul-betul memahami perbedaan budaya antara satu dengan yang lainnya. Akan tetapi, terlalu menekankan pada kata "Orang Lain" (others) dapat membuat seorang individu untuk salah mempersepsikan kelompok budaya lain sebagai entitas monolitik dengan nuansa seragam yang akan melahirkan pola-pola sikap untuk membedakan kelompok tersebut dari kelompoknya sendiri. Karena itu, terlalu menekankan pada perbedaan budaya, tanpa menggarisbawahi perlunya penyadaran terhadap kepercayaan dan asumsi-asumsi budaya sendirinya, secara tidak sengaja dapat berkontribusi terhadap sikap-sikap prasangka dan stereotip terhadap "Orang Lain" yang 
secara budaya berbeda (Chao et al. 2001: 265).

Esensialisme adalah sebuah kepercayaan di mana kategorisasi sosial (seperti ras, etnis, dan gender) memiliki kualitas atau makna yang dalam, yang membuat sifat-sifat sebuah kelompok rentan berubah, padahal memiliki potensi yang sebenarnya unggul. Walaupun, orang-orang tidak mengetahui maknanya, atau bahkan mereka tidak mengerti bahwa sifat dari sebuah kelompok yang diamati terkait dengan makna-makna tertentu, mereka secara sederhana mengasumsikan tentang keberadaan kualitas-kualitas dasar ini dan mengambil kesimpulan berdasarkan makna-makna yang mereka asumsikan itu (Chao et al, 2001: 265).

Penelitian telah menunjukkan saat diberikan dengan bukti minimal tentang bagaimana sifat kesewenang-wenangan berhubungan dengan variabel kategorisasi, individu memiliki tendensi untuk mengekspresikan dan membuat kesimpulan tentang kategorisasi sosial berdasarkan sifat-sifat yang ditanyakan. Sebagai contoh, dalam sebuah percobaan yang pura-pura meneliti bagaimana persepsi seorang individu. Partisipan laki-laki dan perempuan diacak dan diberitahu apakah mereka menjadi orang yang bersikap meninggikan atau merendahkan. Hasilnya menunjukkan bahwa ketika seorang individu belajar bahwa sebuah sifat (ditinggikan atau direndahkan) membedakan mereka dari anggota kelompok gender lainnya, mereka lebih cenderung mengekspresikan perbedaannya dengan memberi makna pada sifat-sifat orang lain dan melihat sifat itu sebagai hal yang menentukan perbedaan-perbedaan gender (Chao et al, 2001: 265-266).
Penemuan-penemuan

ini mempunyai dampak yang signifikan bagi pelatihan kompentensi lintas budaya. Bukti minimal dari kovariasikovariasi dari dua atau lebih variabel yang berkorelasi antara kategori sosial dan sifat-sifat sederhana, sudah mencukupi untuk memperkuat kepercayaan esensialis tentang sebuah kelompok sosial. Dengan penekanan akan pengetahuan terhadap "Orang Lain" yang berbeda, beberapa pelatihan kompetensi lintas budaya mungkin tanpa sadar menyebarluaskan kepercayaan esensialis (Chao et al, 2001: 266).

Esensialisme

telah menstimulasikan banyak diskursus akademik. Penelitian sistematis telah mengungkap bahwa kepercayaan esensialis dapat mewarnai persepsi, sifat, dan penilaian individu-individu, membentuk respon mereka terhadap situasi antar budaya. Sebagai contoh, individu yang mendukung teori esensialis memiliki kecenderungan untuk menyeragamkan kelompok. Mereka memiliki kecenderungan yang lebih besar untuk melakukan stereotip dan berprasangka terhadap kelompokkelompok minoritas, serta memiliki kemungkinan juga untuk merendahkan kelompok di luar mereka. Mereka melihat kelompok-kelompok di luar mereka secara tidak manusiawi (Chao et al, 2001: 266-267).

Sebagai tambahan, pembukaan informasi yang memperkuat kepercayaan esensialis dapat mendorong terjadinya akibat-akibat yang negatif terhadap hubungan antar kelompok, seperti meningkatnya prasangka buruk berkurangnya upaya untuk menyelesaikan masalah-masalah ketidakadilan sosial, dan juga berkurangnya keinginan untuk 
berinteraksi dengan orang lain yang berbeda. Kondisi-kondisi demikian menyarankan bahwa esensialis, yang penekanannya diperkuat pada perbedaan antar kelompok, dapat membawa akibat-akibat negatif pada hubungan antarbudaya maupun antarpersonal (Chao et al, 2001: 267).

Riset lain yang terkait adalah tentang nilai-nilai budaya. Sebuah tinjauan tentang pelatihan-pelatihan lintas budaya mengungkapkan bahwa kurikulum pelatihan umumnya didasarkan pada asumsi bahwa kelompok-kelompok budaya yang berbeda dapat diklasifikasikan bersama dengan dimensi nilai tertentu, seperti individualisme-kolektivisme dan maskulinisme-feminisme (Hofstede, 1980: 102).

Ironisnya, penelitian telah membuktikan bahwa ketidaksamaan nilai yang dipersepsikan terhadap kelompok lain di luarnya, diasosiasikan dengan meningkatnya tingkat permusuhan antar kelompok dan berkurangnya keinginan untuk berinteraksi dengan kelompokkelompok di luarnya itu. Lebih penting lagi, persepsi dari ketidaksamaan nilai ini juga seolah-olah memediasi agresi dan kekerasan terhadap "Orang Lain" yang tidak sama itu. Baik pengaturan klinis maupun organisasional, keduanya dapat diperdebatkan, pelatihanpelatihan kompetensi budaya dan kurikulum yang menekankan pada perbedaan-perbedaan "Orang Lain", tanpa meningkatkan kesadaran individu tentang kepercayaannya sendiri dan asumsi-asumsi lain yang berkembang di seputar kepercayaan tersebut, dapat menjadi bumerang (Chao et al, 2001: 267).

$$
\text { Lebih baik, daripada }
$$
memampukan peserta pelatihan untuk menghargai keberagaman dan untuk bekerja secara efektif di dalam suasana multi-kultural, penekanan yang berlebihan terhadap menyikapi perbedaan-perbedaan ditakutkan malah akan memperkuat sikap stereotip, mengurangi keinginan individu untuk terlibat dalam interaksi antarbudaya, dan dapat membawa pada sikap-sikap permusuhan dan penyerangan antarkelompok. Karena itu, jangan kaget bahwa temuan-temuan riset tentang efektivitas pelatihan lintas budaya ditemukan banyak sekali hasilhasil yang berbeda, dan tidak kesemuanya dapat berakhir optimal (Chao et al, 2001: 267-268).

Untuk meningkatkan tingkat ketahanan personel pasukan perdamaian tidak serta merta semua program pelatihannya harus melibatkan segala sesuatu yang berhubungan dengan relasi interkultural. Program-program pelatihan yang memfokuskan pada bagaimana kita bisa diterima oleh budaya lokal memang penting dan diperlukan sebagai upaya resolusi konflik dan tingkat penerimaan pasukan perdamaian pada sebuah daerah konflik, akan tetapi mengenal budaya sendiri, lalu memperkenalkan budaya tersebut kepada masyarakat lokal juga akan membuat tingkat penerimaan dan penghormatan antar individu dan antar kelompok menjadi terlaksana dengan baik (Chao et al. 2001: 268).

Secara ringkas, banyak programprogram pelatihan yang gagal menimbulkan kompetensi budaya karena fokus pembelajarannya umumnya tentang bagaimana menyikapi bahwa "Orang Lain" itu berbeda. Karena itu, masalah-masalah yang ada diasosiasikan dengan menjadi "Orang Lain" tersebut di dalam sebuah masyarakat. Menjadi kompeten secara 
budaya lebih dari sekedar mengetahui tentang "Orang Lain". Kesadaran tentang kepercayaan yang diri kita sendiri anut adalah kompenen yang tidak bisa dipisahkan yang akan membantu kita mendapatkan kompetensi multi-kultural (Chao et al, 2011: 269).

\section{Meningkatnya Rasa Kesadaran Kompetensi}

Pelatihan kompetensi budaya yang menekankan pada perbedaan budaya tanpa meningkatkan rasa kesadaran si peserta pelatihan sendiri ditakutkan akan menimbulkan kesan bahwa para peserta pelatihan memiliki pengetahuan yang memungkinkan mereka untuk berhadapan dengan kelompokkelompok budaya yang berbeda dan mungkin juga dapat meningkatkan persepsi pribadi mereka terhadap kompetensi budaya. Akan tetapi, dukungan pribadi tersebut belum tentu sesuai dengan kompetensi aktualnya. Sebagai contoh, penelitian Di'azLa'zaro dan Cohen memeriksa konseling dan kondisi psikologi dari para peserta pelatihan terhadap kompetensi multi-kultural mereka yang dilaporkan sebelum mereka berpartisipasi dalam pelatihan tersebut. Mereka menemukan bahwa partisipasi para peserta pelatihan meningkatkan persepsi mereka terhadap kompetensi multi-kultural (Chao et al, 2011: 268).

Walaupun begitu, peningkatan ini tidak serta merta berhubungan langsung dengan peningkatan dalam performa dan kompetensi peserta di lapangan. Sebagai contoh, kompetensi multikultural yang dinilai sendiri diantara para konselor peserta pelatihan meningkat sebagai perbandingan dengan pengamat mandiri tentang peringkat perilaku, dari penilaian rekaman video yang berisi kemampuan mereka tentang kompetensi multikultural (Chao et al, 2001: 268).

Dalam studi lain yang mengamati tentang hubungan antara kompetensi multi-kultural yang dilaporkan sendiri oleh konselor pelatihan dan bias implisit mereka dengan orang Afrika-Amerika, kaum lesbian dan gay. Para konselor pelatihan yang mengikuti program pelatihan dan juga telah mengikuti pelatihan psikologi lintas budaya, dilaporkan lebih memiliki kompetensi secara multi-kultural dibandingkan dengan para peserta pelatihan yang baru sedikit, atau bahkan belum pernah megikuti pelatihan multi-kultural (Levine dan Sutherland, 2008: 195).

Akan tetapi, walaupun kompetensinya meningkat para peserta pelatihan memiliki kecenderungan untuk terus menunjukkan sikap prasangka terhadap kelompokkelompok minoritas, walaupun tingkat pelatihan mereka sudah tinggi dan intensif. Lebih lanjut, dalam studi yang menyelidiki bagaimana para ekspatriat bekerja dalam lingkungan perusahaan multinasional, hasilnya mengungkapkan bahwa walaupun beberapa responden menganggap pelatihan lintas budaya sangat berguna dalam meningkatkan kompetensi mereka untuk menghadapi tantangan yang mereka hadapi di lingkungan budaya baru, studi empiris mengungkapkan bahwa pelatihan tersebut hanya memiliki dampak minimal terhadap penyesuaian hidup para ekspatriat di sana, contohnya kesulitan mereka untuk beradaptasi dengan kehidupan baru di negara asing, tingkat kenyamanan mereka dalam berinteraksi dengan orang lain dalam suasana multi-kultural, dan tentunya penyesuaian mereka terhadap pekerjaan 
mereka di sana (Levine dan Sutherland, 2008: 199).

Bersama-sama, hasil penelitian ini mengusulkan bahwa kompetensi multikultural tidak selalu sesuai dengan kompetensi yang dibutuhkan di lapangan. Tampaknya, pengetahuan dan pelatihan tentang kompetensi multikultural memang dapat meningkatkan kesadaran akan bagaimana menghargai perbedaan, tetapi kondisi demikian belum tentu mampu diaplikasikan sepenuhnya di situasi nyata di lapangan. Di lapangan, kondisinya serba berbeda dengan yang diajarkan (materi) dalam pelatihan. Untuk itu, program pelatihan yang diusulkan harusnya tidak hanya pada pemahaman akan perbedaan saja, tetapi juga bagaimana mengaplikasikannya di lapangan.

$$
\text { Pelatihan yang akan }
$$

diprogramkan nanti untuk para peacekeepers dan keluarganya dalam menghadapi ketahanan budaya tentunya harus memperhatikan hasil-hasil penelitian seperti di atas, serta program yang akan dilatih nantinya juga harus dilengkapi dengan role playing mode, di mana para peserta pelatihan nantinya tidak hanya memiliki kompetensi dan pengetahuan saja, tetapi juga bisa diaplikasikan dalam praktek nyata di lapangan. Dengan adanya role playing, dan juga simulasi-simulasi keadaan di lapangan yang diajarkan sebagai materi pelatihan bagi para peserta, diharapkan dalam tingkatan aplikatif, para peserta pelatihan mampu beradaptasi dengan baik sehingga memiliki tingkat ketahanan yang tinggi dalam menjalankan operasi-operasinya di lingkungan baru.

\section{Ketahanan melawan ke(tidak) mampuan}

Pelatihan-pelatihan budaya yang fokus pada perbedaan-perbedaan budaya saja akan menyebabkan peningkatan kemampuan yang tidak sesuai dan menimbulkan perasaan bersalah, malu, dan tidak kompeten. Hal ini secara khusus benar dalam pelatihan-pelatihan kompetensi budaya yang hanya memfokuskan dirinya pada pengurangan sikap prasangka dalam konteks organisasional dan multikultural (Chao et al, 2011: 271).

Pertama-tama, penekanan yang berlebihan tentang pemahaman istilah "Orang Lain" dapat menggiring individu untuk merasa bahwa mereka sudah memiliki tingkat pengetahuan yang cukup tentang perbedaanperbedaan budaya, dan dengan demikian mereka menganggap tidak perlu dilakukan pelatihan-pelatihan tambahan, seperti memahami budayanya sendiri dan juga materimateri yang berkaitan dengan bagaimana meningkatkan ketahanan budaya di lapangan (Chao et al. 2011: 271).

Kedua, dan yang lebih penting, penekanan terhadap pengurangan sikap berprasangka dengan pengertian bagaimana membedakan "Orang Lain", ternyata malah menguatkan asumsiasumsi yang menyatakan bahwa prasangka dan sikap permusuhan tinggal di dalam diri para perserta pelatihan. Dari sudut pandang seperti itu, sebuah saran untuk mengintervensi pengurangan sikap berprasangka yang diajarkan dalam pelatihan tersebut dipandang sebagai sebuah tuduhan negatif bagi para peserta pelatihan, malah saran tersebut dianggap sebagai sebuah prasangka negatif terhadap materi pelatihan seperti ini. Hal ini dapat menimbulkan perlawanan dan resistensi, mengurangi motivasi individu untuk ikut serta dalam 
pelatihan-pelatihan kompetensi budaya (Chao et al, 2011: 271).

Sebuah penelitian interventif dengan menggunakan remaja didesain utuk mengurangi stereotip rasial dan prasangka negatif. Penelitian ini memeriksa reaksi dari siswa kelas 9 yang ikut berpartisipasi dalam penelitian ini. Mereka diambil dari kelas Ilmu Pengetahuan Sosial di sebuah SMA Negeri di pinggiran Negara Bagian Los Angeles sekitar tahun 20022003. Intervensi ini diberikan diberikan selama 7-8 jam dalam sebuah sesi pelajaran dengan tema ras, etnisitas. Orientasi seksual, dan gender dengan pesan keseluruhan yang ingin disampaikan adalah tentang mengurangi prasangka-prasangka negatif dalam kehidupan sehari-hari mereka, contohnya seperti pertemanan, pacaran, dan keterlibatan dalam geng-geng) (Chao et al, 2011: 272).

Analisa yang didapatkan dari hasil focus group discussions (FGD) yang dilakukan selama dua minggu dengan para siswa tersebut, mengungkapkan secara garis besar hasil evaluasi yang bersifat negatif dari pelajaran yang menyikapi permasalahan terkait dengan ras dan etnisitas. Sebagai contoh, banyak dari siswa-siswa tersebut yang menegaskan bahwa pelajaran tentang mengurangi sikap prasangka adalah tidak banyak berguna, karena mereka memang tidak bersikap demikian dan mereka tidak menilai orang lain berdasarkan ras atau warna kulit (Chao et al, 2011: 272-273).

Orang lain juga dapat mengatakan bahwa pelajaran-pelajaran seperti itu tidaklah relevan atau menarik bagi mereka karena mereka tinggal dan datang ke sekolah di mana suasananya sangat menghargai perbedaan, serta sejak sekolah dasar mereka sudah diajarkan untuk tidak bersikap rasis. Untuk itu, pelatihan bagi para peacekeeper harus diidentifikasikan sejak dini, mana saja yang bisa dimasukkan kurikulum yang sesuai untuk para peserta pelatihannya sendiri. Banyak yang sejak kecil sudah tumbuh dari budaya-budaya heterogen, sehingga bisa menerima perbedaan dan cenderung diterima oleh orang lain dengan budaya yang berbeda. Indentifikasi calon peserta pelatihan bagi peacekeepers menurut penulis juga penting agar tujuan-tujuan yang diharapkan dari pelatihan-pelatihan lintas budaya dapat tercapai dan tepat sasaran (Chao et al, 2011: 273).

Untuk itu, cara-cara dan strategi lain diterapkan untuk menghilangkan masalah-masalah prasangka rasial di sekolah, di mana para siswanya tidak megkritisi pelatihan atau pelajaran yang diberikan dengan istilah "tidak penting" lagi. Bahkan lebih dari itu, cerita-cerita dari banyak siswa mengungkapkan bahwa mereka melihat implementasi dari intervensi pengurangan sikap prasangka sebagai sebuah tuduhan yang ditujukan kepada mereka karena rasisme dianggap tinggal di dalam diri mereka. Hasil-hasil ini menyarankan bahwa pelatihan-pelatihan kompetensi budaya yang memfokuskan dirinya pada mengurangi prasangka terhadap perbedaan "Orang Lain" dapat menjadi bumerang, memunculkan sikap-sikap defensif, dan mengurangi motivasi orang untuk ikut serta dalam pelatihanpelatihan seperti itu lagi (Chao et al, 2011: 273-274).

\section{Pelajaran yang didapat}

Era globalisasi mendekatkan ragamragam budaya yang ada di seluruh dunia dan menampilkan tantangan-tantangan yang unik kepada para profesional- 
profesional dari segala macam disiplin ilmu di seluruh dunia. Pentingnya kompetensi budaya dalam hal ini tidak bisa terlalu ditekankan. Banyak sumber daya telah diinvestasikan dalam mengembangkan kurikulum dan pelatihan-pelatihan untuk mempromosikan kompetensi budaya. Walaupun kesadaran, pengetahuan, dan kemampuan itu dilihat sebagai komponen-komponen penting dari pemahaman kompetensi budaya, pelatihan-pelatihan dan kurikulum memiliki kecenderungan untuk lebih menitikberatkan pada aspek pengetahuannya, untuk mempelajari tentang perbedaan yang "Orang Lain" miliki.

Seperti yang sudah dibahas sebelumnya, penekanan yang timpang terhadap perbedaan dapat mengarah pada kompetensi multi-kultural yang meningkat, jika terjadi secara normal. Tetapi, jika tidak yang terjadi adalah konsekuensi yang negatif antarkelompok dan cenderung bersikap defensif dengan tidak blend in dengan kelompok lain. Untuk menyampaikan masalah ini, pelatihan kompetensi budaya harus mengubah penekanannya dengan mulai mencatat pentingnya untuk memeriksa secara kritis kepercayaan, nilai, dan prasangka yang dimiliki masing-masing individu, dalam rangka untuk meningkatkan kesadaran terkait dengan identitas sosial dan budaya mereka sendiri.

Apakah disebutnya kesadaran budaya atau kesadaran kritis, asumsi di mana seorang individu harus berhadapan dengan instropeksi reflektif dari posisi sosial mereka, harus menjadi mantra dalam pelatihan dan latihan multikultral. Kesadaran kritis menyangkut menjadi sadar dari prasangka-prasangka eksplisit dan implisit terkait posisi masing-masing identitas dan cara-cara di mana sifatsifat dan prasangka-prasangka dapat mempengaruhi interaksi antara satu orang dengan orang lain.

Sekali kepercayaan implisit terbawa dalam kesadaran untuk peduli, seorang individu dapat melanjutkan untuk membangun pengetahuan dan kemampuan budaya yang lebih sesuai atau tepat, yang diperlukan untuk mengatasi situasi secara efektif di mana masyarakatnya plural. Lebih lanjut, seorang individu dapat juga mengambil keuntungan dari pelatihan-pelatihan kompetensi budaya yang bertujuan untuk mengembangkan nuansa pemahaman budaya yang melampaui batas-batas etnis dan budaya. Sebagai tambahan, penelitian yang memeriksa pelatihan lintas budaya menemukan bahwa diantara berbagai karakteristik kepribadian, keterbukaan dari individuindividu tersebut secara sangat signifikan telah dikaitkan dengan pelaksanaan hasil akhir pelatihan (Saltzman et al, 2011: 218).

Keterbukaan dikarakterisasikan dengan sifat-sifat berikut, yaitu sensitivitas dan kesadaran yang dirasakan oleh hati kita yang paling dalam dan kesiapan untuk merefleksikan nilai-nilai tradisional kita. Melihat dari pentingnya menyadari kesadaran pribadi kita dalam pelatihan kompetensi budaya, sangatlah tidak mengherankan ketika individu-individu tersebut yang lebih terbuka terhadap pengalaman-pengalamannya mendapat banyak keuntungan dari pelatihan tersebut (Saltzman et al, 2011: 219).

Walaupun, keterbukaan memiliki kecenderungan untuk dikonseptualisasikan sebagai sifat yang umumnya stabil, langkah-langkah dapat diambil untuk meningkatkan tingkat 
keterbukaan dan kesiapan individu terhadap pelatihan-pelatihan kompetensi budaya. Sebagai contoh, daripada menggarisbawahi pentingnya memahami perbedaan "Orang Lain" dan menafsirkan sifat prasangka sebagai sebuah sifat yang berada di dalam diri semua orang, sifat prasangka dan diskriminasi dapat dikonseptualisasikan menjadi sebuah fenomena sistemik tertanam di dalam masyarakat sebagai masalah-masalah struktural, di mana masyarakatnya secara keseluruhan perlu melawan (Saltzman et al, 2011: 219).

Bahkan, penelitian terbaru telah menunjukkan bahwa individu dapat lebih terbuka dan dapat menuruti kebijakan antirasis secara lebih siap, jika mereka berhadapan dengan pelatihan kompetensi budaya yang mengkonseptualisasikan rasisme sebagai fenomena sosial budaya yang dapat ditanggulangi, daripada sebagai sifat yang selalu ada dalam diri setiap individu. Untuk itu, perlunya memiliki sumber daya pasukan penjaga perdamaian yang mampu membedakan dua konsep ini sangatlah penting bagi kelangsungan misi-misi perdamaian PBB (Cacioppo et al, 2001: 48).

Satu hal juga yang harus diperhatikan bagi peacekeepers dalam menghadapi masalah lintas budaya ini adalah tentang asumsi-asumsi pribadi mereka yang membuat mereka tidak mampu bersosialisasi atau diterima di masyarakat. Karenanya, berikut akan dijelaskan beberapa item yang bisa dipertimbangan untuk menganalisa dan memahami sebuah budaya:

- Bagaimana pembagian kerja masyarakatnya, yang bisa diidentifikasi melalui gender, umur, ras, kelas sosial, etnis, kasta (jika ada), dan faktor-faktor budaya yang relevan lainnya.
- Bagaimana hubungan kekerabatan atau pertalian darah masyarakatnya, apakah matrilineal atau patrilineal? Apakah terdiri dari klan-klan atau menurut garis keturunan? Bagaimana struktur keluarga mempengaruhi orang lain?

- Bagaimana afiliasi agama atau sistem kepercayaan masyarakatnya terkait dengan konflik horisontal yang bisa terjadi?

- Bagaimana tingkat pendidikannya dan apakah tingkat pendidikan terkait dengan faktor-faktor primordial, seperti gender, kelas sosial, ras, umur, kasta (jika ada), dll?

- Bagaimana sebuah kelompok masyarakat tertentu di sana membedakan dirinya dengan kelompok lain? Apa saja kriterianya? Siapa yang dianggap kawan, siapa yang dianggap lawan? Apakah ada perasaan ingroup atau outgroup di sana?

- Terakhir, bagaimana hubungan masyarakatnya (local people) dengan otoritas yang lebih tinggi, seperti otoritas pemerintahan, otoritas agama, lembaga internasional, dll? (Eade 2007: 59-60).

Lebih lanjut, dirasa cukup penting juga untuk mendorong pertumbuhan yang potensial dan membangun kompetensi untuk meningkatkan motivasi dan mempertahankan keterbukaan terhadap pelatihan kompetensi budaya. Sebuah studi intervensi terbaru telah menunjukkan bahwa dengan menggarisbawahi kemungkinan pertumbuhan dan perubahan, individu lebih bersedia untuk berkonfrontasi melawan prasangka dan diskriminasi, dan memiliki sifat-sifat positif yang lebih banyak terhadap interaksi antarbudaya di masa depan. Hendaknya pelatihan 
yang akan disarankan bagi para peacekeepers ini juga sadar akan permasalahan ini (Chao et al, 2011: 269-270).

\section{Program Latihan \\ Dikembangkan Kanada}

yang

Di bagian ini kita akan melihat sedikit tentang pola program yang pernah dilakukan pasukan Kanada adalah Peace Support Training Centre (PSTC) di Kingston, Kanada. Di sini kita akan mencoba menelaah seperti apa Peace Support Training Centre (PSTC) dalam kaitannya dengan kompetensi lintas budaya dan ketahanan para pasukan penjaga perdamaian PBB dalam menjalankan misi-misi perdamaiannya.

PSTC sendiri bertanggung jawab untuk melatih semua pasukan Kanada yang dipilih untuk diterjunkan secara individu, dengan kata lain mereka bukanlah bagian dari sebuah kontingen atau unit. PSTC menawarkan dua tipe kursus atau pelatihan, yang dijadwalkan sepanjang tahun. Sebuah pelatihan dasar selama lima hari untuk para anggota yang dipilih untuk menjalani operasioperasi internasional dan pelatihan selama delapan belas hari untuk perwira-perwira yang dipilih untuk mengisi posisi sebagai pengamat militer (Peace Operation Training Institute, 2007).

Dalam upayanya untuk meningkatkan standar pelatihan secara global, PSTC menjaga hubungan dekat dengan lembaga-lembaga lain di seluruh Kanada dan seluruh dunia, dan mendorong pertukaran instruktur antar lembaga-lembaga tadi, serta membagi materi-materi pelatihan. Pelatihan ini juga terbuka untuk para perwira-perwira dari negara lain. Sebagai tambahan untuk pelatihan individu, harus juga dicatat bahwa PSTC memiliki dua tim asistensi untuk pelatihan yang menyediakan nasihat-nasihat tentang operasi perdamaian, asistensi dan bantuan untuk unit-unit dan kontingenkontingen yang telah dibentuk, baik di Kanada sendiri, maupun di luar negeri (Peace Operation Training Institute, 2007).

PSTC mengambil baik teoritis melalui pengajaran-pengajaran di ruang kelas, maupun pendekatan praktis melalui latihan-latihan di lapangan dan simulasi. Pendekatan-pendekatan model ini sangat baik untuk diterapkan pada program peningkatan kompetensi budaya dan ketahanan para peacekeepers, terutama pendekatan praktisnya. Hal ini karena dengan terlibat langsung dalam simulasi dan role playing situation, para peacekeepers mampu menganalisa langsung problem apa yang muncul di lapangan, serta mekanisme apa yang paling sesuai untuk mengatasinya. Secara tidak langsung pun akan menguatkan ketahanan para peacekeepers di dalam setiap penugasannya dalam lingkungan baru dan asing secara budaya (Peace Operation Training Institute, 2007).

Pendekatan-pendekatan yang digunakan dalam pelatihan ini mencari cara untuk mempersiapkan para peacekeepers agar mampu menjalankan tugasnya dengan baik ketika ditempatkan dalam lingkungan yang meningkat tingkat kompleksitasnya. Untuk itu, peserta pelatihannya menerima pemahaman secara umum tentang topik-topik berikut, seperti hukum untuk konflik bersenjata, resiko dan ancaman, manajemen stres, pengobatan untuk pencegahan, kesadaran akan bahaya ranjau, teknik negosiasi dan mediasi, dan kesadaran 
budaya (Peace Operation Training Institute, 2007).

Selain PSTC, tahun 1960-an dibentuk Military Training Assistance Programme (MTAP) yang bertujuan untuk membantu militer di negaranegara persemakmuran, dan sampai hari ini program MTAP masih didanai dan dijalankan sepenuhnya oleh Departemen Pertahanan Nasional (DND) Kanada. Tiap tahun, program ini melatih lebih dari 1300 peserta pelatihan dari sekitar 60 negara. Program ini tidak hanya memperkuat pasukan peacekeepers Kanada, tetapi juga membantu pengembangan kapasitas pasukan asing dan meningkatkan kecocokan dengan pasukan Kanada (Rasilius, 2001).

Program ini memiliki tiga tujuan. Pertama, adalah pelatihan bahasa yang berguna untuk berkomunikasi kepada sesama pasukan internasional. Kedua, pengembangan profesional dan pelatihan untuk staf, yang berguna untuk meningkatkan operabilitas diantara beberapan kontingen negara asing yang berbeda. Dan ketiga, pelatihan operasi pendukung perdamaian ini bertujuan untuk meningkatkan pemahaman perdamaian, oleh peserta dari militer maupun sipil, seperti operasi peaceekeping multilateral dan operasi-operasi peacekeeping lainnya (Rasilius, 2001).

Selanjutnya adalah Pearson

Peacekeeping Centre (PPC) yang berdiri tahun 1994, dan didukung oleh pemerintah Kanada, militer, polisi, dan masyarakat sipil dari seluruh dunia. Lembaga ini awalnya hanya memberikan pelatihan terkait pentingnya pelatihan dasar militer untuk mendukung operasi perdamaian, contohnya seperti pengembangan dari konsep pertolongan pertama, intervensi yang dilakukan antara faksi-faksi yang bertikai, manajemen stres, kemampuan bertahan hidup, dan penggunaan kekuatan (The Pearson Centre, tanpa tanggal).

Seiring berjalannya waktu, materi pelatihan tambahan pun dirasa penting karena dianggap belum cukup mumpuni untuk mempersiapakan para pasukan menghadapi kejamnya perang. Inovasiinovasi baru yang up to date akhirnya diberikan karena dianggap sebagai alat persiapan yang sangat vital. Salah satu contohnya adalah lobi dan tempat makan United Nations Association di Kanada, ternyata memainkan peranan penting dalam proses pelatihan. Hal ini karena di tempat-tempat tersebutlah para peserta pelatihan yang terdiri dari berbagai negara membagi cerita dan pengalamannya (The Pearson Centre, tanpa tanggal).

Dewasa ini, program riset yang ekstensif dilakukan melalui seminarseminar dan lokakarya-lokakarya, dan juga mengorganisir pelatihan-pelatihan yang bersifat lintas keilmuan dan berskala multinasional. Sebagai tambahan, PPC telah secara aktif juga mendukung Kofi Annan International Peacekeeping Training Centre (KAIPTC) di Ghana dan The West Africa Police (The Pearson Centre, tanpa tanggal).

\section{Ketahanan Sosial di Militer}

Ketahanan telah dianggap sebagai kepemilikan pribadi yang klasik. Akan tetapi, ketahanan sosial secara inheren adalah sebuah pembangunan bertingkat, ditunjukkan tidak hanya dengan kapasitas masing-masing individu, tetapi juga kelompok-kelompok, untuk memelihara, ikut serta, dan menunjang hubungan-hubungan sosial yang positif, serta untuk menanggung dan pulih dari 
stres dan isolasi sosial. Secara sederhana, ketahanan dapat diartikan sebagai kemampuan untuk mengatasi, beradaptasi, dan menanggulangi tantangan. Dengan pelatihan yang dilakukan untuk meningkatkan ketahanan para peacekeepers dan keluarganya, mereka tidak hanya belajar untuk menghadapi tantangan-tantangan, tetapi juga menjadi lebih kuat dalam mengatasinya (FOCUS, tanpa tanggal).

Berikut adalah beberapa modul yang dapat diberikan bagi pelatihanpelatihan untuk para pasukan penjaga perdamaian untuk mengembangkan kemampuan ketahanan sosial mereka. Program ini menyangkut empat modul yang masing-masing berdurasi 15 menit. Setiap modul didesain untuk mendorong kesadaran akan satu atau lebih sumber daya personal secara spesifik. Sebagai contoh, modul pertama menampilkan beberapa sumber daya personal, termasuk "merasa terhubung dengan individu dan kolektif lain" (contohnya dalam sebuah kelompok, pasukan, atau tim), "memahami orang lain secara lebih akurat dan empatik", dan "mengadopsi nilai-nilai yang mendorong kesejahteraan diri sendiri dan orang lain" (Cacioppo et al, 2001: 47).

Konsep dari ketahanan sosial bagi tentara adalah memperkenalkan sebuah konsep di mana si tentara fokus pada dirinya sendiri, dan pada perannya sebagai anggota dari sebuah tim yang lebih besar, berangkat dari kata "saya" menjadi "kami". Hubungan antara ketahanan sosial dengan tujuh nilai-nilai utama dari militer (kesetiaan, tugas, menghormati, melayani tanpa mengutamakan diri sendiri, kehormatan, integritas, dan keberanian diri) dijelaskan secara detail di tingkatantingkatan dalam organisasi, dan bagaimana hubungan-hubungan ini dapat meningkatkan ketahanan sosial (Cacioppo et al, 2001: 47). Intinya adalah tentara akan lebih mudah untuk bertarung secara efektif dan beradaptasi terhadap situasi buruk dan tantangan-tantangan yang mereka akan hadapi, apabila mereka lebih terbuka tentang hal-hal yang ada di sekeliling mereka, seperti tim mereka contohnya, daripada hanya memikirkan diri mereka sendiri. Satu tantangan terhadap ketahanan sosial adalah dengan melihat orang lain secara berbeda dari diri mereka sendiri dan sebagai kelompok luar yang lebih dianggap sebagai ancaman daripada sumber daya (Cacioppo et al, 2001: 47).

Modul yang kedua mengilustrasikan bagaimana perbedaan diantara para anggota dari suatu pasukan atau tim dapat membuat kelompok itu lebih kuat, lebih mudah beradaptasi, dan tentunya memiliki ketahanan yang baik. Kesadaran juga dibuat dari kemungkinan-kemungkinan bahwa kepaduan dalam sebuah pasukan atau tim lebih penting daripada kekuatan dan bakat dari seorang individu unggul, dan perbedaanperbedaan dari semua elemen yang ada dalam satu kelompok tersebut dapat meningkatkan kemampuan kelompok itu untuk beradaptasi ketika menghadapi tantangan dan masalah baru. Toleransi dan keterbukaan menjadi dasar utama dari modul ini (Cacioppo et al, 2011: 47)

Di dalam modul ketiga, informasi yang disediakan adalah tentang kebutuhan yang melekat dalam diri setiap individu untuk membentuk hubungan-hubungan yang bermakna dengan orang lain, maupun kecenderungan setiap manusia untuk meniru sesamanya, untuk bergabung 
bersama-sama, berkomunikasi dengan sesama, dan untuk membagi perasaan juga kepada sesamanya. Modul ini menyediakan menggarisbawahi pendapat bahwa setiap individu mempengaruhi satu sama lainnya, baik secara sengaja maupun tidak, dan pengaruh ini bisa bersifat positif maupun negatif (Cacioppo et al. 2001: 47-48).

Intinya sekali lagi adalah, agar tentara dapat bertempur lebih efektif, serta mampu mengatasi secara efektif pula tantangan-tantangan yang mereka hadapi, ketika mereka bergerak dan berpikir sebagai sebuah kesatuan dalam tim, daripada sebagai seorang individu belaka. Dengan melakukan ini, modul ini mengarahkan para peserta pelatihan untuk memahami tiga hal ini: merasa terhubung dengan individu dan kelompok lainya, kemampuan untuk menanggapi secara lebih tepat terhadap masalah-masalah sosial, dan mengungkap emosi sosial secara lebih tepat dan efektif. Sifat eksperimental dari modul ini memang dirancang untuk memperkuat materi-materi yang sudah tercakup dalam modul-modul sebelumnya dan untuk memotivasi para tentara untuk mengambil pelajaran berarti dari modul-modul yang sudah dipelajari ini dan mengaplikasikannya di dalam kehidupan sehari-hari (Cacioppo et al, 2001: 48).

Modul yang terakhir fokus pada pengembangan kemampuan sosial peserta pelatihan dan menyediakan informasi khusus tentang bagaimana cara menciptakan aliansi dengan orang lain. Nilai-nilai yang harus dikembangkan dalam modul ini adalah, menghormati orang lain, menilai orang lain secara objektif, dan mempromosikan kesejahteraan diri sendiri dan juga orang lain. Modul ini memperkenalkan konsep ABCDEs: (A)

hadir dengan niat tulus; (B) bertanggungjawab terhadap perkataan yang diucapkan; (C) peduli terhadap orang lain dan menerima persepsi mereka bagimanapun berbedanya dengan persepsi kita; (D) jangan menyela, tetapi tunggu hingga mereka selesai; dan (E) menyemangati orang lain untuk berbicara lebih banyak dan agar orang itu pun merasa aman jika berbicara dengan kita (Cacioppo et al, 2001: 48).

Menikmati masa-masa indah bersama memang sangat penting bagi persahabatan, tetapi justru saling berbagi kesulitan yang akan menjadi lem yang merekatkan ikatan-ikatan sosial. Modul terakhir ini mengakui bahwa dalam masa-masa perang akan terjadi saat-saat indah,maupun saat-saat kita berduka, dan para tentara harus mengetahui apa artinya menjadi seorang teman, sekaligus anggota tim yang baik di dalam masa-masa sulit. Akhirnya, para peserta pelatihan harus mengerti pentingnya kepercayaan untuk membangun ketahanan sosial dalam hubungan sosial mereka dengan orang lain. Model pelatihan seperti ini sangat baik jika kita terapkan untuk meningkatkan kompetensi lintas budaya dan ketahanan para peacekeepers di mana pun mereka berada (Cacioppo et al, 2011: 48-49).

\section{Program Ketahanan Keluarga}

Problem besar muncul di kalangan para pasukan penjaga perdamaian (semua tentara juga mengalaminya), yaitu ketika mereka harus meninggalkan keluarganya untuk bertugas dalam misimisi perdamaian di negara lain. Untuk itu, perlu juga kita menyediakan program-program pelatihan untuk meningkatkan family resiliency. 
Ketahanan (resilience) sendiri berasal dari kata latin "resilire" yang artinya "leap back", dan berasal dari dua kajian psikologi: aspek-aspek psikologis dari stres dan aspek-aspek psikologi untuk mengatasinya (Levine dan Sutherland, 2008:193).

Setelah di awal kita banyak bicara tentang bagaimana meningkatkan kompetensi lintas budaya dan ketahanan para peacekeepers di daerah konflik, maka sekarang kita akan melihat sedikit tentang bagaimana meningkatkan ketahanan para keluarga peacekeepers tersebut jika ditinggalkan bertugas oleh orang yang mereka cintai. Karena dukungan keluarga adalah sebuah konsep multi-dimensional, di mana memiliki keterkaitan yang signifikan dengan ketahanan dan perkembangan anggota-anggota di dalamnya (Levine dan Sutherland, 2008: 203).

Untuk menyikapi hal tersebut, Departemen Pertahanan dan Angkatan Laut Amerika Serikat telah mengembangkan sebuah program yang mengedepankan konsep pendekatan terhadap keluarga tentara berdasarkan kepentingan untuk menopang kesehatan psikologis dan kesiapan perang dari para tentara AS, serta kesehatan jangka panjang dan perkembangan para anakanak dan keluarga tentara-tentara tersebut. Nama program tersebut adalah Families Overcoming Under Stress disingkat FOCUS (Marine Corps Community Service Camp Lejeune, tanpa tanggal). Mereka-mereka yang terlibat di FOCUS merupakan kolaborasi unik dari akademisi dan pusat-pusat kajian yang berpusat pada masyarakat di seluruh dunia, yang misinya adalah untuk menaikkan standar pelayanan dan meningkatkan akses terhadap pelayanan untuk anakanak penderita trauma dan keluarga mereka di seluruh Amerika Serikat (UCLA Health System, 2008).

FOCUS adalah program latihan yang dirancang untuk meningkatkan ketahanan keluarga tentara yang mengalami tingkat stres yang tinggi dan juga untuk mencegah masalah yang lebih besar untuk terjadi di masa depan. FOCUS bertujuan untuk menguatkan kohesi di dalam keluarga, hubungan antara orang tua-anak, suami-istri, dan pengasuhan terhadap anak. Area-area yang dapat dikembangkan melalui FOCUS, seperti aturan-aturan emosional, komunikasi, pemecahan masalah, agenda tujuan, dan menangani trauma dan hilang ingatan. Kompetensi utama dari program FOCUS adalah adanya enam sampai delapan sesi pelatihan, dengan sesi khusus untuk orang tua, sesi khusus untuk anak, dan sesi khusus yang melibatkan seluruh anggota keluarga. Bahkan, jika ayahnya sedang tugas, sesi tetap bisa dilakukan secara jarak jauh (Saltzman, 2011: 214).

FOCUS bekerja untuk pasangan dalam meningkatkan kemampuan komunikasi dan pemahaman akan pengalaman masing-masing pasangan. Ketika bekerja dengan keluarga dengan anak antara umur 3-5, FOCUS memperkuat kemampuan orang tua dalam hal pengasuhan anak dan membangun pengertian orang tua terhadap tingkah laku anak ketika menghadapi stres. Ketika bekerja dengan tentara yang terluka dalam perang dan keluarganya, FOCUS membantu keluarga menyesuaikan diri dengan perubahan-perubahan khusus yang terjadi, terkait dengan kondisi cedera yang dialami (Marine Corps Community Service Camp Lejeune, tanpa tanggal).

Untuk meningkatkan ketahanan keluarga, beberapa langkah berikut bisa 
dimasukan dalam program-program pelatihan. Pertama, menyediakan edukasi psikologis dan bimbingan perkembangan diri. Ketika anggota keluarga mengetahui beratnya tingkat stres yang mereka hadapi, mereka dibenarkan dari perasaan malu atau tuduhan terhadap kelemahan atau pergumulan mereka. Anak-anak pun mengerti bahwa ketika orang tua mereka marah, dan akhirnya bertindak tidak pantas, itu semata-mata bukan karena kesalahan anak itu sendiri. Jadi, anak-anak bisa terlibat dalam proses pemecahan masalah bersama anggota keluarga lainnya. Dibekali informasi seperti ini, semua anggota keluarga dapat mengerti dan memahami satu dan lainnya (Saltzman et al, 2011: 220-221).

Kedua, membagi kisah-kisah keluarga. Dengan menyediakan sebuah forum khusus yang aman bagi anggota keluarga untuk membagi pengalamannya, reaksinya, bahkan kekhawatirannya. Forum ini dapat membantu meningkatkan ketahanan para anggota keluarga. Ketiga, dalam proses membagi cerita masing-masing anggota keluarga, konselor dapat menyoroti pada kekuatan yang dimiliki keluarga tersebut, maupun personal masing-masing anggotanya, ketika menegaskan keberhasilan-keberhasilan di masa lalu dalam menangani tantangan-tantangan serupa (Saltzman et al, 2011: 221).

Keempat, meningkatkan empati dan komunikasi keluarga. Ketika ceritacerita tentang pengalaman, dll dibagikan, masing-masing anggota keluarga merasa aman untuk mengekspresikan perasaan pribadi mereka. Hal ini mampu meningkatkan tingkat empati dalam keluarga karena masing-masing anggota keluarga belajar untuk menghargai pemikiran anggota yang lain, bahkan perbedaannya sekalipun (Saltzman et al, 2011: 221).

Kelima, mendorong komunikasi yang terbuka dan efektif. Ciri khas dari keluarga yang sehat adalah bersikap langsung (blak-blakan), jelas, konsisten, dan jujur dalam berkomunikasi, dan toleran. Karakteristik seperti ini penting bagi keluarga yang mengalami stres karena salah satu anggota keluarga ada yang dikirim berperang. Penting bagi FOCUS untuk bekerja dengan tidak melepaskan diri dari kerangka personal dan budaya masing-masing keluarga, dan membantu mereka untuk menemukan cara yang paling sesuai untuk menyelesaikan masalah-masalah yang timbul (Saltzman et al, 2011: 222).

Keenam, meningkatkan kemampuan ketahanan keluarga. Kemampuan khusus yang diajarkan pada ebuah keluarga dapat membantu keluarga tersebut untuk mengantisipasi dampak dari kondisi yang mengakibatkan stres. Beberapa kemampuan khusus ini termasuk pengelolaan stres, pemecahan masalah, penanganan trauma, dan ingatan yang hilang. Semua kemampuan ini sangat baik diterapkan pada sebuah keluarga untuk meningkatkan ketahanan mereka (Saltzman et al, 2011: 222).

\section{Kesimpulan}

Di dalam berkembangnya dan semakin cepat globalisasi menjalar ke seluruh dunia, mengerti dan memahami perbedaan-perbedaan budaya telah menjadi salah satu hal yang sangat penting bagi pasukan perdamaian PBB dalam menjalankan misinya di seluruh dunia. Budaya telah menjadi sangat diverse sehingga tidak ada budaya global atau lokal yang menjadi patokan dalam masyarakat multi-kultural dewasa ini. untuk itu, peacekeepers 
harus memahami dan memiliki kompetensi lintas budaya, serta ketahanan sosial dan budaya yang mumpuni untuk bisa menjalankan tugasnya dengan optimal.

Para peacekeepers harus mengerti perbedaan kombatan dan bukan kombatan. Karenanya, diperlukan sensitivitasan yang tinggi untuk dapat bertindak sebagai seorang penjaga perdamaian yang profesional, karena kita tidak bisa sekedar melihat dengan kacamata hitam putih belaka. Pengetahuan yang dalam tentang budaya begitu penting dalam misi-misi perdamaian antara lain karena hal-hal demikian. Peacekeepers bukanlah ordinary soldiers, mereka punya tanggung jawab yang lebih besar daripada sekedar menjalankan tugastugas kemiliteran. Apalagi sekarang keterlibatan sipil di misi-misi perdamaian tersebut semakin memegang peranan penting.

Untuk meningkatkan tingkat ketahanan personel pasukan perdamaian tidak serta merta semua program pelatihannya harus melibatkan segala sesuatu yang berhubungan dengan relasi interkultural. Program-program pelatihan yang memfokuskan pada bagaimana kita bisa diterima oleh budaya lokal memang penting dan diperlukan sebagai upaya resolusi konflik dan tingkat penerimaan pasukan perdamaian pada sebuah daerah konflik, akan tetapi mengenal budaya sendiri, lalu memperkenalkan budaya tersebut kepada masyarakat lokal juga akan membuat tingkat penerimaan dan penghormatan antar individu dan antar kelompok menjadi terlaksana dengan baik.

Pusat-pusat pelatihan bagi pasukan perdamaian dewasa ini juga harus bersifat multi cabang. Artinya, tidak khusus hanya diperuntukkan untuk personel militer, tetapi juga bisa diaplikasikan kepada orang sipil, dan pihak-pihak lain yang terkait. Termasuk juga dengan menyertakan programprogram ketahanan budaya kepada para keluarga peacekeepers. Karena itu, program ini penting juga menyertakan orang-orang yang pernah berpengalaman dalam misi-misi perdamaian sebelumnya, tentunya yang mampu mengatasi permasalah lintas budaya, agar mereka dapat memberikan pengalamannya bertugas untuk diterapkan pada sesi-sesi pelatihan.

Beberapa model pelatihan bisa diterapkan untuk program peningkatan kompetensi budaya dan ketahanan para peacekeepers, terutama pendekatan praktisnya. Hal ini karena dengan terlibat langsung dalam simulasi dan role playing situation, para peacekeepers mampu menganalisa langsung problem apa yang muncul di lapangan, serta mekanisme apa yang paling sesuai untuk mengatasinya. Secara tidak langsung pun akan menguatkan ketahanan para peacekeepers di dalam setiap penugasannya dalam lingkungan baru dan asing secara budaya.

Untuk meningkatkan tingkat ketahanan para keluarga peacekeepers, salah satu program yang dikembangkan Departemen Pertahanan dan Angkatan Laut Amerika Serikat bernama FOCUS bisa jadi satu piliham. FOCUS adalah program latihan yang dirancang untuk meningkatkan ketahanan keluarga tentara yang mengalami tingkat stres yang tinggi dan juga untuk mencegah masalah yang lebih besar untuk terjadi di masa depan. FOCUS bertujuan untuk menguatkan kohesi di dalam keluarga, hubungan antara orang tua-anak, suamiistri, dan pengasuhan terhadap anak, 
sehingga family resiliency dapat terbangun.

Setelah memaparkan sekelumit masalah-masalah yang dihadapi pasukan penjaga perdamaian dan keluarganya, serta usulan programprogram pelatihan untuk meningkatkan kompetensi lintas budaya dan ketahanan bagi mereka, maka beberapa rekomendasi yang dapat disampaikan di sini adalah sebagai berikut:

1. Harus ada penambahan pelatihanpelatihan yang diselenggarakan PBB untuk menguatkan kemampuan kompetensi lintas budaya bagi pasukan penjaga perdamaian, baik sipil maupun militer, di setiap misimisi perdamaian $\mathrm{PBB}$ di seluruh

\section{DAFTAR PUSTAKA}

BBC Indonesia, 2011. "Chat Rekrut Anak-Anak sebagai Tentara." Diunduh 29 Oktober 2012 (http://www.bbc.co.uk/indonesia/ dunia/2011/02/110210_chadchild army.shtml).

Cacioppo, J. T, Hary T. Reis, dan Alex J. Zautra. 2001. "Social Resilience: The Value of Social Fitness with an Application to the Military." American Psychologist 66, (1): 43-51.

Tanpa tanggal. "Human trafficking: An overview." Catholic Relief Service. Diunduh 15 Oktober 2012 (http://crs.org/publicpolicy/in_depth.cfm).

Chao, M. M, Sumie Okazaki, dan Yingyi Hong. 2001. "The quest for multicultural competence: Challenges and lessons learned from clinical and organizational research." Social and Personality Psychology Compass 5(5): 26374. dunia, dan dilakukan secara permanen.

2. Materi pelatihan yang diberikan harus lebih mengedepankan aspekaspek multi-kultural dan penghargaan terhadap keberagaman dan kesadaran budaya lokal.

3. PBB harus mengembangkan program-program ketahanan, baik sosial maupun budaya, bagi keluarga pasukan penjaga perdamaian.

4. Pentingnya dibuat program-program ketahanan bagi keluarga, seperti FOCUS (Families Overcoming Under Stress) yang ada di Amerika Serikat, di setiap negara-negara yang terdapat misi perdamaian PBB.

Darby, J. dan Roger Mac Ginty. 2003. Contemporary peacekeeping: Conflict, violence, and peace processes. New York: Palgrave Macmillan.

Eade, D. 2007. Capacity-building: An approach to people centered development. United Kingdom: Oxfam.

Tanpa tanggal. "What is Resiliency?" Family Resiliency Training for Military Families. (n.d). Diunduh $10 \quad$ Oktober 2012 (http://www.focusproject.org/how -it-works/resiliency-training).

Harian Analisa, 2012. "Militer AS Disorot Tajam Terkait Kebijakannya tentang Prostitusi." Diunduh 15 Mei 2012

(http://www.analisadaily.com/news/read /2012/05/15/50911/militer_as_dis orot tajam terkait kebijakannya tentang_prostitusi/\#.UHvizWdYh Go).

Hofstede, G. 1980. Culture's consequences: international 
differences in work related values. Sage: Beverly Hills.

Levine, K dan Dawn Sutherland. 2008. "The Impact of an Informal Career Development Program on the Resilience of Inner-city Youth." h. 193-214 di Resilience in action, diedit Linda Liebenberg dan Michael Ungar. Toronto: University of Toronto Press.

Tanpa tanggal. "What is the FOCUS project." Marine Corps Community Service Camp Lejeune. Diunduh 13 Oktober 2012

(http://www.mccslejeune.com/foc us/index.html).

Office of the Special Adviser on Gender Issues and Advancement of Women, 2000. "Landmark Resolution on Women, Peace and Security." Diunduh 15 Oktober 2012

(http://www.un.org/womenwatch/ osagi/wps/).

Peace Operation Training Institute, 2007. "The Canadian Force Peace Support Training Center." Diunduh 7 November 2012 (http://www.peaceopstraining.org/ e-learning/cotipso/partner/45/).

Rasilius, A. P. 2001. "The Military Training Assistance Programme (MTAP): An Instrument of Military Diplomacy." Canadian Military Journal 2, 3: 63-64. Diunduh 16 Oktober 2012 (http://www.forces.gc.ca/admpol/ content.asp?id $=\{0836 \mathrm{DC} 33-$ B9C2-4329-9F01589BE14CD880\}).
Saltzman, W. R, Patricia Lester, William R. Beardslee, Christopher M. Layne, Kirsten Woodward, dan William P. Nash. 2011. "Mechanisms of risk and resilience in military families: Theoretical and empirical basis of a family-focused resilience enhancement program." Clinical Child and Family Psychology Review 14(3): 213-30.

Tanpa tanggal. "The Pearson Centre". Peace Operations. Diunduh 7 November 2012 (http://www.peaceoperations.org/ en/index.asp).

UCLA Health System, 2008. "Helping military families help themselves."

Diunduh 7 November 2012

(http://www.uclahealth.org/body.cfm?id $=403 \&$ action $=$ detail \&ref $=1053$ )

\section{Biodata Penulis}

Jerry Indrawan, S.IP, M.Si (Han). Lahir di Jakarta 26 Agustus 1984 Menyelesaikan program sarjana di Program Studi Ilmu Politik, Institut Ilmu Sosial dan Ilmu Politik Jakarta tahun 2010 dan program magister Ilmu Pertahanan di Universitas Pertahanan Indonesia tahun 2014. Saat ini mengabdi sebagai dosen tetap di Program Studi Ilmu Politik UPN "Veteran" Jakarta. Mengajar Ilmu Politik dan Hubungan Internasional di UPN "Veteran" Jakarta, Universitas Paramadina, dan Universitas Satya Negara Indonesia. Fokus kajian pada bidang Politik Pertahanan, Studi Keamanan dan Strategi, dan Studi Perdamaian. 